\title{
Familial multiple myeloma. A review of thirty-seven families
}

\author{
Y. SHOENFELD* \\ M.D. \\ M. SHAKLAI $\dagger$ \\ M.D.
}

\author{
S. BERLINER* \\ M.D.
}

L. A. Gallant*

M.D.

\author{
J. Pinkhas* \\ M.D.
}

Department of *Medicine ' $D$ ', $\dagger$ The Hematology Clinic, Tel Aviv University Sackler School of Medicine, Beilinson Medical Center, 49100 Petah Tiqva, Israel

\begin{abstract}
Summary
The review of the pertinent literature disclosed 36 reports of familial multiple myeloma, described mostly in siblings, to which the authors add one more family. These patients did not differ significantly from those with non-familial myeloma with regard to sex, age, distribution of monoclonal proteins, clinical and laboratory data, and the course and prognosis of the disease. An increased incidence of immunoglobulin abnormalities was observed in healthy relatives of patients affected with familial myeloma. In most cases the time interval of the diagnosis of myeloma in a family member of a known patient was under 4 years. These observations, in conjunction with reports of myeloma occurring in clusters in a community and the appearance of myeloma in spouses raise the possibility of an environmental factor (virus?) which may contribute to the pathogenesis of myeloma in genetically predisposed individuals.

Multiple myeloma should be added to the list of neoplastic diseases in which the family history is relevant and in which genetic and possibly environmental factors may be pathogenetically involved.
\end{abstract}

\section{Introduction}

The aetiology of plasma cell dyscrasia remains an enigma despite recent experimental and clinical observations suggesting a genetic predisposition (Zawadzki et al., 1977). The familial occurrence of multiple myeloma (MM) implies a possible hereditary element, since the incidence of familial MM is higher than can be accounted for by chance alone (Grant, Blumenschein and Bickley, 1971). The discovery that a particular HLA type occurs more frequently in patients with $\mathrm{MM}$ than in the general population further supports the view that genetic factors play a role in determining the susceptibility of man to this disease. In support of this hypothesis the authors report on another case of familial MM and review the pertinent literature.

\section{Family report}

Case 1

A 78-year-old housewife was admitted in 196安t the Beilinson Medical Center because of extremes weakness and dizziness. Her past history was remarkable in that she had suffered from recurreng bronchopneumonia and urinary tract infection during the 12 months preceding her admission. OR admission, marked pallor was noted and a few w rales were heard over the bases of both lungs. The spleen and the liver were not palpated.

The ESR (Westergren) was $100 / 114 \mathrm{~mm} / \mathrm{hr}$, the $\mathrm{Hb} 8.1 \mathrm{~g} / \mathrm{dl}$, haematocrit $27 \%$, the WBC $4.2 \times 10^{\circ} \mathrm{H}$ with a normal differential count and the platelef. count was $108 \times 10^{9} / \mathrm{l}$. The BUN was $3 \mathrm{mmol} / \mathrm{e}$ uric acid $0.49 \mathrm{mmol} / \mathrm{l}$ and the calcium $2.35 \mathrm{mmol} / \mathrm{t}$. Protein electrophoresis disclosed a monoclonas peak identified as IgG with lambda light chain, the concentration of which was $3.6 \mathrm{~g} / \mathrm{l}$. The $\operatorname{IgA}$ was 0.6 and $\operatorname{IgM} 0.2 \mathrm{~g} / 1$. Lambda Bence-Jones proteinut ria was detected. A bone marrow aspiration biops revealed sheets of immature plasma cells. The skeletal X-ray survey revealed widespread osteoporosis with compressed fracture in the lumbap $\left(\mathrm{L}_{1-2}\right)$ vertebrae.

\section{Case 2}

The 63-year-old son of Case 1 was admitted t the hospital 11 years later (1980) because of extreme weakness. Tests established the diagnosis of IgGT lambda MM with lambda Bence-Jones proteinuriơ 
as well as widespread osteolytic lesions. The immunoglobulin levels were $\operatorname{IgG} 8.0 \mathrm{~g} / \mathrm{l}, \operatorname{IgA} 0 \cdot 12$ $\mathrm{g} / \mathrm{l}$ and $\operatorname{IgM} 0.22 \mathrm{~g} / \mathrm{l}$. The other routine blood examinations were within normal limits.

\section{Survey of familial aggregates}

There are 21 reports of 36 familial instances of

TABLE 1. Survey of familial aggregates

\begin{tabular}{lc}
\hline Family relationship & $\begin{array}{c}\text { No. of } \\
\text { Case reports }\end{array}$ \\
\hline Brother and sister & 10 \\
Two brothers & 8 \\
Two sisters & 6 \\
Mother and son & 3 \\
First degree cousins & 3 \\
Mother and daughter & 2 \\
A patient and her aunt & 1 \\
Brother, sister and nephew & 1 \\
Father (probably), son and daughter & 1 \\
Brother, sister, another sister (probably) & 1 \\
\hline
\end{tabular}

MM (Table 1) most of which involved siblings. Sister-brother relationships were found in 10 instances (Alexander and Benninghoff, 1965; Maldonado and Kyle, 1974; Meijers, Leeuw and Voormolen Kalova, 1972; Nadeau, Magalini and Stefanini, 1956; Takekuma et al., 1968; Zawadzki et al., 1977), brother-brother in 8 (Grossman et al., 1963; Herrell, Ruff and Bayrd, 1958; Law, 1976; Maldonado and Kyle, 1974; Robbins, 1967; Wiedermann et al., 1976; Zawadzki et al., 1977) and sister-sister in 6 instances (Barbieri and Grampa, 1972; Hirsch and Schwarz, 1959; Leoncini and Korngold, 1964; Maldonado and Kyle, 1974; Mandena and Wildervanck, 1954; Manson, 1961). Maternal consanguinity was found in 6 instances (Boga et al., 1973; Goldstone, Wood and Cook, 1973; Manigand et al., 1970; Meijers et al., 1972; Zawadzki et al., 1977; present report). Another report described 2 children of a father who probably had MM, who were affected with this disease (Nadeau et al., 1956). Relationships between first degree cousins were noted in 3 instances (Riccardi, DiGirolomo and Parziali, 1966; Zawadzki et al., 1977) and there was one report of a patient and her aunt with MM (Spengler et al., 1966-1967). In one, and probably in 2 other reports, more than 2 family members had MM: a brother, sister and nephew kinship was reported in one (Meijers et al., 1972), 2 children of a father who probably had MM were presented in a second (Nadeau et al., 1956), and 3 (probably) siblings were reported in a third case history (Zawadzki et al., 1977).

\section{Incidence}

During the years 1968-1977, the authors followed- up 94 patients with $\mathrm{MM}$ and thus, their 2 patients with familial MM represent an incidence of $2 \cdot 1 \%$.

\section{Sex and age}

There were 31 males and 28 females, the mean \pm s.d. ages at the time of diagnosis being $63 \cdot 2 \pm 9 \cdot 3$ and $63 \cdot 1 \pm 9 \cdot 2$ years respectively.

\section{Type of monoclonal protein}

Exact identification of the monoclonal protein was included in reports published only within the last years. There were 15 instances of IgG myeloma, 7 with $\kappa$ light chains (Boga et al., 1973; Law, 1976; Maldonado and Kyle, 1974; Wiedermann et al., 1976; Zawadzki et al., 1977), 3 with $\lambda$ light chains (Maldonado and Kyle, 1974; present case report), and in 5 instances the type of the light chain was not determined. In 6 instances, there was IgA MM Boga et al., 1973; Goldstone et al., 1973; Manigand et al., 1970; Wiedermann et al., 1976; Zawadzki et al., 1977) and in one IgG MM (Takekuma et al., 1968). There was one case history in which biclonal IgG $\kappa$ IgA MM appeared in only one family member. The same type of monoclonal protein was found in the present patients, in an additional 3 families reported in the literature (Law, 1976; Maldonado and Kyle, 1974) and probably in another family in which 2 sisters had ' $\beta$ MM' (Barbieri and Grampa, 1972). Distribution of the type of immunoglobulin does not seem to differ significantly from that existing in non-familial MM (Pick et al., 1979, 1977).

\section{Plasmacytoma and MM}

The occurrence of plasmacytoma and MM was documented in only one family (Case Records, 1973).

Other malignancies in the patients with familial MM

In addition to MM, 2 patients contracted breast tumours (Maldonado and Kyle, 1974; Thomas, 1964) and another one had thyroid and adrenal adenomas (Boga et al., 1973).

Other malignancies in the patients' family members not affected with $M M$

In the series of Maldonado and Kyle (1974) 2 brothers of patient no. 5-1-10 died of adenocarcinomas of the pancreas and kidney respectively, the brother of patient no. 8-11-2 had an adenocarcinoma of the pancreas and a maternal cousin of this patient died from "carcinoma of the female organs'. Lung carcinoma was reported in another instance.

Time interval between the diagnoses

In 15 instances (Goldstone et al., 1973; Herrell 
et al., 1958; Law, 1976; Leoncini and Korngold, 1964; Maldonado and Kyle, 1974; Manigand et al., 1970; Nadeau et al., 1956; Robbins, 1967; Thomas, 1964; Wiedermann et al., 1976; Zawadzki et al., 1977) the diagnosis of familial MM was made within 4 years, in 4 instances (Law, 1976; Maldonado and Kyle, 1974; Manigand et al., 1970) within one year and in the remaining instances the time interval was between 4 and 11 years.

\section{Immunoglobulins in family members}

Festen et al. (1977) recorded the serum immunoglobulin concentrations of 200 first-degree relatives of 32 patients with $\mathrm{MM}$ and found higher serum concentrations of $\operatorname{IgG}, \operatorname{IgA}$ and IgM than in their age- and sex-matched controls. Other authors (Berlin, Odeberg and Weingart, 1968; Grant et al., 1971; Law, 1976; Maldonado and Kyle, 1974; Manigand et al., 1970; Meijers et al., 1972; Nadeau et al., 1956; Wiedermann et al., 1976; Zawadzki et al., 1977) examined a total of 133 family members and noted quantitative abnormalities in 12 of them $(9 \%)$.

\section{MM in spouses}

There were 6 instances of MM in spouses (Kardinal, 1978; Kyle, Heath and Carbone, 1971; Pietruszka, Rabin and Srodes, 1976). The time interval between the diagnoses ranged from one month to 15 years.

\section{$M M$ in clusters}

There is but one report of $\mathrm{MM}$ occurring in a cluster (Kyle, Herbes and Evate, 1970).

Clinical and laboratory data, course and prognosis The symptoms and signs, laboratory and radiological data, bone marrow findings, serum and urine electrophoresis, and the course and prognosis did not differ significantly from those usually observed in patients with $\mathrm{MM}$.

\section{Discussion}

A survey of the medical literature disclosed reports of 36 familial instances of MM, a fact that raises the possibility of the existence of some genetic factors that, at least in some of the patients, may contribute to the development of this plasma cell dyscrasia. This hypothesis is strengthened by the laboratory investigations conducted in the last decade, showing that genetic factors may play an important role in the induction of plasma cell tumours: the intra-peritoneal injections of mineral oil stimulated the formation of these tumours only in inbred mice of the BALB/c or NZB strains (Bergsagel, 1977). Attempts to induce plasmacytomas by intraperitoneal oil injection in hybrids of BALB/c or NZB mice with mouse strains resistant to plasma cell tumour induction produce very few tumours (Potter, 1972). It appears therefore, tha BALB/c and NZB mice are unique in having. specific genes involved in the pathogenesis of plasma cell tumours and that at least one gene is recessive (Bergsagel, 1977). In man, McKusick (1966) accepts a genetic basis for the cases of familial occurrence of $M M$ and includes this disease in the list of autosomal recessive disorders.

Familial paraproteinaemia is not limited to patients with MM and has been described in patients with Waldenström's macroglobulinaemia (Grant et al., 1971), benign monoclonal gammopathog (Axelsson and Hällen, 1965) and other types of immunocytic dyscrasias including amyloidos (Zawadzki et al., 1977), chronic lymphatic leukaemia (Zawadzki et al., 1977), cryoglobulinaemiø (Waterman et al., 1979) and various lympho' reticular neoplasms (Zawadzki et al., 1977). Morer over, the incidence of immunoglobulin abnormat lities in the families of patients with familial MNS appears to be increased (Festen et al., 1977), a fact that further supports a genetic predisposition for these immunopathies. In addition to the report of Festen et al. (1977) of statistically significant in creased serum immunoglobulin concentration in first degree relatives of patients with myelomatogifo the sum of all other reports in which increasedp serum immunoglobulins were found in other fafill members of MM patients revealed a total incidence of $9 \%$. The occurrence of paraproteinaemia in the population above 50 years of age without evidenge of MM was reported by Hällen (1963) to be $3 \%$ Pick et al. recently (1979) reported 170 patients wit benign monoclonal gammopathy among 3000 patients examined from 1968 to 1977, establishing an incidence of $0.56 \%$. Thus it appears that at incidence of $9 \%$ for familial immunopathies is patients with familial $\mathbf{M M}$ is greater than that anticipated by chance alone.

Boga et al. (1973) summarized the possibilities fơ monoclonal immunoglobulin synthesis within $\mathrm{g}$ family as follows: asymptomatic (benign) monos clonal component in several members of the same family; asymptomatic (benign) monoclonal com ponent in members of the family of a patiet suffering from MM (or Waldenström's macröglobulinaemia); overt MM (or Waldenströmo̊ macroglobulinaemia) in 2 or more members of the same family.

This suggests that families of patients with plasmfar cell dyscrasia should be examined. Such a poliey is not merely academic, since every patient wi asymptomatic monoclonal gammopathy should carefully followed-up as it has been reported that the latter may herald the manifestation of MM (Bergsagel, 1977). 
Except for the 4 case reports (Law, 1976; Maldonado and Kyle, 1974; and the present report), the appearance of the types of monoclonal protein in family members, in all other instances where the monoclonal protein was identified, was not identical. The lack of identity of the electrophoretic pattern among most patients with familial MM does not necessarily indicate diverse aetiologies of the appearance of the monoclonal protein. In fact, it is known that within a given major immunoglobulin class (for example IgG) many different antibody specificities may be found and in addition distinctive major immunoglobulin classes (for example IgG or IgM) can emerge in response to the same antigenic stimulation (Bergsagel, 1977).

In most families, less than 4 years elapsed between the diagnosis of $\mathrm{MM}$ among the different family members, and in 4 instances (Law, 1976; Maldonado and Kyle, 1974; Manigand et al., 1970) the diagnosis was established within less than one year of the first one. This observation together with 6 reports of the appearance of MM in spouses (Kardinal, 1978; Kyle et al., 1971; Pietruszka et al., 1976), a report of seasonal variations in this disease (McPhedran, Heath and Garcia, 1972), and one report of MM in a community cluster (Kyle et al., 1970) raises the possibility that some external factor (such as a virus) is involved in the pathogenesis of the disease in genetically predisposed people. In fact, the likelihood that a virus may be involved in the pathogenesis of MM is supported by the observation of virus-like particles in myeloma cells (Sorenson, 1961; Sorenson, 1965). Studies in mice have frequently revealed intra-cisternal $A$ particles in cases of plasma cell tumours (Dalton, Potter and Merwin, 1961). Two varieties of type ' $C$ ' particles have been also reported in murine plasma cell tumours (Potter, 1973). Another possible association within viruses is provided by the Aleutian disease of minks. The features of this disease include widespread proliferation of plasma cells, diffuse hyperglobulinaemia and in some animals a monoclonal serum protein and Bence-Jones proteinuria (Porter, Dixon and Larsen, 1965). This entity is readily transmissible by cell-free extracts of affected mink tissue, and appears to be a virus-induced neoplastic overgrowth of the plasma cell system. Thus, the possibility that an external factor (virus?) may be involved in the pathogenesis of MM in genetically predisposed people may be plausible. However, there are cases, such as the presently reported family, in which the MM was diagnosed within an 11-year interval of each other, raising the possible involvement of slow viruses.

The reason for the increased prevalence of $M M$ in siblings among patients with familial $\mathbf{M M}$ is unknown. One may speculate as to whether siblings are in contact for prolonged periods during which a chronic stimulus could exert its effect on them. In fact, chronic antigenic stimulation has been proposed as a factor predisposing to the development of MM in man (Bergsagel, 1977).

The sex distribution, the average age of the patient and the distribution of the various types of monoclonal immunoglobulins did not differ significantly from similar criteria in non-familial MM (Kyle and Bayrd, 1975; Meijers et al., 1972; Pick et al., 1979, 1977) nor were there differences in the clinical and laboratory data, and the course and prognosis (Kyle and Bayrd, 1975). Thus it seems that familial and non-familial MM belong to the same clinical entity, the only difference between them being a genetic predisposition.

Few patients or their family members had a history of other malignancies. It is known that patients with one malignancy might have an increased tendency to develop another (Kyle et al., 1976). Weitzel (1958) reported an incidence of $19.3 \%$ of carcinomatous processes in patients suffering from malignant plasma cell dyscrasia. The increased number of patients with MM terminating in acute leukaemia could be related to an increased incidence of secondary malignancies in these patients or to the effect of chemotherapy (Bergsagel, 1977). In the present report, the relatively few instances of other malignancies in the patients and their families could be due to chance alone, especially considering the relatively old age of these patients.

Familial MM has been illustrated only in relatively few instances and since in most reports the number of patients with monoclonal gammopathy was not mentioned, it is difficult to estimate the exact incidence of familial MM. The incidence in the present report $(2.1 \%)$ is similar to the $2.5 \%$ incidence reported by Robbins (1967). However, the occurrence of MM in more than one member of a family is significant and represents more than a chance association and, therefore, careful attention to the family history is warranted (Maldonado and Kyle, 1974).

It is concluded that MM should be added to the list of neoplastic diseases in which the family history is relevant and in which genetic and possible environmental factors may play some role in its pathogenesis.

\section{References}

Alexander, L.L. \& Benninghoff, D.L. (1965) Familial multiple myeloma. Journal of the National Medical Association, 57, 471.

AXELSSON, U. \& HÄLlen, J. (1965) Familial occurrence of pathological serum-proteins of different gamma-globulin groups. Lancet, ii, 369.

Barbieri, D. \& Grampa, A. (1972) Familiarità nel mieloma 
multiplo: 'beta' mieloma in due sorelle. Haematologica. Pavia, 58, 565.

Bergsagel, D.E. (1977) Plasma cell myeloma. In: Hematology (Ed by Williams, W.J., Beutler, E., Ersler, A.J. \& Rundler, R.Y.), 2nd edn, pp. 1090, 1099-1126. McGraw Hill Book Co.,

Berlin, S.O., Odeberg, H. \& Weingart, L. (1968) Familial occurrence of M-components. Acta medica scandinavica, $183,347$.

Boga, M., Jako, J., Doman, J., Magyar, E. \& Konyar, E. (1973) Familial myeloma. Folia haematologica. Leipzig, 100, 201.

Case Records of the Massachusetts General Hospital (Case 45261) (1959) New England Journal of Medicine, 260, 1336.

Dalton, A.J., Potter, M. \& Merwin, R.M. (1961) Some ultrastructural characteristics of a series of primary and transplanted plasma cell tumor of the mouse. Journal of the National Cancer Institute, 26, 1221.

Festen, J.J.M., MARRINK, J., WAARD-KNIPER, E.H. \& MANDEMA, E. (1977) Immunoglobulins in families of myeloma patients. Scandinavian Journal of Immunology, 6, 887.

Goldstone, A.H., Wood, J.K. \& CooK, M.K. (1973) Myeloma in mother and daughter. Acta haematologica, 49, 176.

Grant, J.A., Blumenschein, G.R. \& Bickley, C.E. (1971) Familial paraproteinemia. Archives of Internal Medicine, 128, 427.

Grossman, L.A., Ownby, F.D., Grossman, M., Kaplan, J.H. \& WolfE, L.K. (1963) Multiple myeloma in brothers. Journal of the Tennessee Medical Association, 56, 398.

HÄLlEN, J. (1963) Frequency of 'abnormal' serum globulins (M-components) in the aged. Acta medica scandinavica 173, 737.

Herrell, W.E., Ruff, J.D. \& Bayrd, E.D. (1958) Multiple myeloma in siblings. Journal of the American Medical Association, 167, 1485.

Hirsch, V.W. \& Schwarz, G. (1959) Multiple Myeloma bei Geschwistern. Medizinische Klinik, 54, 1624.

Isobe, T. \& Osserman, E.F. (1971) Pathologic conditions associated with plasma cell dyscrasias: a study of 806 cases. Annals of the New York Academy of Sciences, 190, 507.

Josephs, B.N., Robbins, G. \& Levine, A. (1962) Polycythemia secondary to hamartoma of the liver. Journal of the American Medical Association, 179, 867.

KARDINAL, C.G. (1978) Multiple myeloma in a husband and wife. Journal of the American Medical Association, 239, 22.

KYLE, R.A. \& BAYRD, E.D. (1975) Monoclonal gammopathies In: Hematology (Ed by Linman, J. W.), p. 753. Macmillan Publishing Co. Inc., New York.

Kyle, R.A., Heath, C.W. \& Carbone, P. (1971) Multiple myeloma in spouses. Archives of Internal Medicine, 127, 944.

Kyle, R.A., Henderson, E.S., Randolph, V.L. \& Budge, W.R. (1976) Multiple myeloma, acute leukemia and Hodgkin's disease. Cancer, 37, 1496.

Kyle, R.A., Herbes, L. \& Evate, B. (1970) Multiple myeloma. Journal of the American Medical Association, 213, 1339.

LAW, M.I.P. (1976) Familial occurrence of multiple myeloma. Southern Medical Journal, 69, 46.

LeONCINI, D.L. \& KoRNGOLD, L. (1964) Multiple myeloma in 2 sisters. Cancer, 17, 733.

McKusick, V.A. (1966) Mendelian Inheritance in Man, p. 2365. The Johns Hopkins Press, Baltimore.

McPhedran, P., Heath, C.W. \& Garcia, J. (1972) Multiple myeloma incidence in metropolitan Atlanta, Georgia: racial and seasonal variations. Blood, 39, 866.
Maldonado, J.E. \& KYlE, R.A. (1974) Familial myeloma American Journal of Medicine, 57, 875.

MANDENA, E. \& WildervancK, L.S. (1954) La maladie de Kahler (myélomes multiples) chex deux soeurs. Journal de Génétique Humaine, 3, 170.

Manigand, G., Sarrazin, A., Demuth, L., Schoen, E Deparis, M., Roparty, C. \& Rival, L. (1970) Maladie de Kahler familiale. Presse Médicale, 78, 1741.

Manson, D.I. (1961) Multiple myeloma in sisters. Scottis Medical Journal, 6, 188.

MeiJers, K.A.E., Leeuw, B. \& Voormolen-Kalova, MP. (1972) The multiple occurrence of myeloma and asymptôn matic paraproteinaemia within one family. Clinical and Experimental Immunology, 12, 185.

Nadeau, L.A., Magalini, S.I. \& Stefanini, M. (1956) Familial multiple myeloma. Archives of Pathology, 6ty 101.

Pick, A.I., Shoenfeld, Y., FrohlichmanN, R., Weiss, H囬 VANA, D. \& Schreibman, S. (1979) Plasma cell dyscrasią Journal of the American Medical Association, 241, 2275. iv

Pick, A.I., Shoenfeld, Y., Skvaril, F., Schreibman, Sọ FrohlichmanN, R., Weiss, H. \& Pinkhas, J. (1977g Asymptomatic (benign) monoclonal gammopathy- of study of 100 patients. Annals of Clinical and Laboratory Sciences, 7, 335.

Pietruszka, M., Rabin, B. \& Srodes, C. (1976) Multip myeloma in husband and wife. Lancet, $\mathbf{i}, 314$.

Porter, D.D., Dixon, F.J. \& LARsen, A.E. (1965) The development of a myeloma-like condition in mink wi苗 Aleutian disease. Blood, 25, 736.

POTTER, M. (1972) Immunoglobulin-producing tumors an myeloma proteins of mice. Physiological Reviews, 52, $63 \mathrm{~L}$

PotTer, M. (1973) The development history of the neoplift plasma cells in mice: a brief review of recent development Seminars in Hematology, 10, 19.

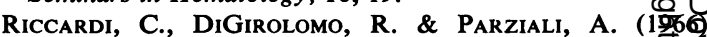
Mieloma multiplo familiarie. Progresso Medico, 22, 822 .

RobBins, R. (1967) Familial multiple myeloma. America Journal of Medical Sciences, 254, 98/848.

SORENSON, G.D. (1961) Electron microscopic observations 용 viral particles within myeloma cells of man. Experimentat Cell Research, 25, 219.

SoRENSON, G.D. (1965) Virus-like particles in myeloma celi of man. Proceedings of the Society for Experimentat Biology and Medicine, 118, 250.

Spengler, G.A., Butler, R., Fischer, C., Ryssel, H.J SCHMID, E. \& SiEBNER, H. (1966-1967) On the question familial occurrence of paraproteinemia. Helvetia medicta acta, 33, 208.

Takekuma, N., Kagiomoto, T., Tajiri, M., Horie, ISER, Y., KAWAKITA, Y. \& Migita, T. (1968) IgD argi IgG myeloma in siblings. Acta haematologica. Japan, 3\$3 468.

Thомаs, R.F. (1964) Multiple myeloma in siblings. Ney

York State Journal of Medicine, 64, 2096.
WATERman, J.R., Winkelstein, J.A., BerzofsKy, R.N HsU, S.H., BIAS, W.B. \& ARNETT, F.C. (1979) Earfy complement component depletion and mixed cry氶 globulinemia in a 'healthy' family. Arthritis and Rheumatism, 22, 1006.

WeItZEL, R.A. (1958) Carcinoma is existent with malignaft disorders of plasma cells; an autopsy survey. Cancer, $\underbrace{1}$ 546.

Wiedermann, D., Urban, P., Wiedermann, B. \& Cidl, (1976) Multiple myeloma in two brothers. Immunaglobulin levels among their relatives. Neoplasma, 23, 19

Zawadzki, Z.A., Aizawa, Y., KraJ, M.A., Haradin, A.Z \& FisHer, B. (1977) Familial immunopathies. Cancer, 40, 2094. 